$15^{\text {th }}$ International Conference on

AEROSPACE SCIENCES \& AVIATION TECHNOLOGY,

ASAT - 15 - May 28 - 30, 2013, Email: asat@mtc.edu.eg,

Military Technical College, Kobry Elkobbah, Cairo, Egypt,

Tel: +(202) $24025292-24036138$, Fax: +(202) 22621908

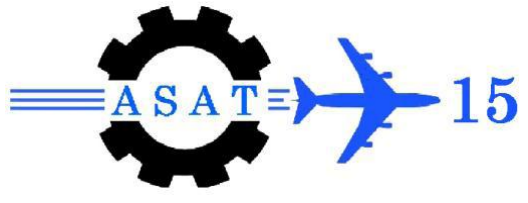

\title{
Experimental and Theoretical Investigation of Ultimate Strength of Rectangular Hollow Section Tapered Columns
}

\author{
A. H. Salem ${ }^{*}$, N. H. Abdelmtaal ${ }^{\dagger}$, M. M. Abd Al-whhab ${ }^{\dagger}$, and Z. Al-Yassin ${ }^{\ddagger}$
}

\begin{abstract}
This paper focuses on the strength and behavior of rectangular hollow sections (RHSs) tapered columns subjected to uniform axial loads. Within this work, seven columns with different shapes and dimensions were tested under concentric loading. Numerical analysis using FEM Software ANSYS is performed on the tested models and the results are compared with the experimental results. After this verification of the FE model a parametric study was carried out. The column strengths predicted from the parametric study were compared with the design strengths calculated using the American (AISI-2001) and European (EN-1993) specifications.
\end{abstract}

Keywords: Finite element analysis, Ultimate strength, tapering ratio, hollow section columns.

\section{Nomenclature}

$\mathrm{L} \quad$ plate length (length of column), (mm)

$\mathrm{d}_{\mathrm{w} 2} \quad$ Wide web width, $(\mathrm{mm})$

$\mathrm{d}_{\mathrm{w} 1} \quad$ narrow web width, $(\mathrm{mm})$

$\mathrm{t}$ plate thickness, $(\mathrm{mm})$

$\mathrm{d}_{\mathrm{f}} \quad$ flange depth, $(\mathrm{mm})$

$\lambda \quad$ plate slenderness $=\left(\mathrm{d}_{\mathrm{w} 2} / \mathrm{t}\right)$

E Young's modulus of elasticity, $\left(\mathrm{N} / \mathrm{mm}^{2}\right)$

$\mathrm{V} \quad$ Poisson's ratio

$\mathrm{P}_{\mathrm{u}}^{\text {tes }} \quad$ ultimate capacity obtained by experimental test

$\mathrm{P}_{\mathrm{u}}^{\mathrm{F} . \mathrm{E}} \quad$ ultimate capacity obtained by finite element analysis

$\mathrm{P}_{\mathrm{y} . \mathrm{av}} \quad$ yield capacity $=\sigma_{\mathrm{y}} \cdot \mathrm{A}_{\mathrm{av}}$.

$\mathrm{P}_{\mathrm{n}} \quad$ nominal axial strength

$\sigma_{\mathrm{n}} \quad$ design stress, $\left(\mathrm{N} / \mathrm{mm}^{2}\right)$

$\mathrm{A}_{\mathrm{e}} \quad$ effective area, $\left(\mathrm{mm}^{2}\right)$

$\delta \quad$ Elongation.

$\sigma_{\mathrm{y}} \quad$ yield stress, $\left(\mathrm{N} / \mathrm{mm}^{2}\right)$

$\mathrm{R} \quad$ tapering ratio $=\left(\mathrm{d}_{\mathrm{w} 2} / \mathrm{d}_{\mathrm{w} 1}\right)$

$\gamma_{\mathrm{M} 1} \quad$ safety factor for the resistance due to overall yielding

$\chi \quad$ reduction factor for flexural buckling

Structural Engineering Department, Ain Shams University, Cairo, Egypt.

$\dagger \quad$ Egyptian Armed Forces, Egypt.

* Syrian Arabic Armed Forces, Syria; abeerzouf@yahoo.com 


\section{Introduction}

Compression members are commonly used as columns in building structures, chords or webs in trusses, bridge piers or braces in framed structures. Also can be used in hangars, industrial buildings and in the construction of wings, tails and fins of aircrafts. The strength of a stiffened compression element is governed by yielding if its slenderness $\left(\lambda=\mathrm{d}_{\mathrm{w} 2} / \mathrm{t}\right)$ is relatively small. It may be governed by local buckling at a stress level less than the yield point if its slenderness is relatively large. The behavior of hollow section columns, under the action of compressive stress uniformly distributed along the edges was discussed by several authors, such as:

Bridge and Shea [1] performed a comprehensive series of tests to examine the behavior of short, thin-walled, square steel tubes under axial load with or without internal restraint.

Young [2] presented the experimental and numerical investigation of the design and behavior of cold-formed high strength stainless steel tubular columns with square and rectangular hollow sections with fixed ends.

Yang, Hancock and Rasmussen [3] presented a series of compression tests performed on pinended long columns with box-sections fabricated from cold-formed high strength steel plates with nominal yield stress of $550 \mathrm{MPa}$.

Salem et al. [4] presented a numerical analysis to investigate the ultimate loads and the failure modes of axially loaded steel columns composed of cold-formed rectangular hollow sections (RHS).

Kuwamura [5] experimentally investigated local buckling behaviours of thin-walled stainless steel columns. Six types of sections: angle, lipped channel-shaped, square box, and circular cylindrical sections were tested.

Korashy, et,al [6] presented a finite element model including both geometrical and material non-linearities for thin-walled box section beam-columns subjected to axial load and bending moment.

Dabaon, et al. [7] presented a numerical modeling to study the strength and behavior of stainless steel stiffened and unstiffened hollow-section columns under uniform axial loads.

Masoudnia, et,al [8] presented the behavior of steel columns with square hollow sections formed by four welded equal angle sections, two welded channel sections and box sections that were subjected to the axial thrust.

\section{Test Specimens}

Seven compression tests were performed on thin-walled hollow rectangular section pin-ended tapered columns. The dimensions and symbols are showed in Figure 1. The nominal dimensions and length for each column are tabulated in Table 1. The seven columns specimens have been divided into two series according to the source of material and place of manufacture. The first series consists of four specimens manufactured at Al-Zamil company from steel 37, while the second series includes three specimens manufactured in a workshops at Sabtia. 


\section{Material Properties}

For each column, tensile coupon was taken from the center of flat flange (web) of each column after completing the column test. The shape of the standard tensile coupon is shown in Figure 2.The mechanical properties of each tensile coupon used are presented in Table 2.

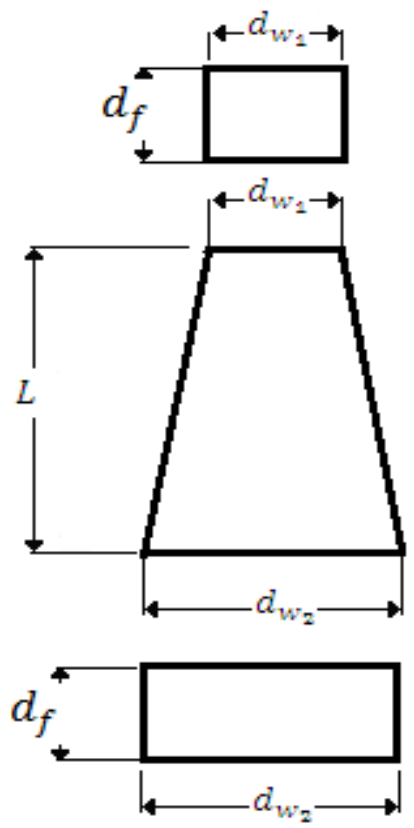

Fig. 1 The dimension and symbols of columns

Table 1. Dimensions of the columns

\begin{tabular}{c|c|c|c|c|c|c|c}
\hline $\begin{array}{c}\text { Source of } \\
\text { Material }\end{array}$ & Specimen & $\begin{array}{c}\mathrm{L} \\
(\mathrm{mm})\end{array}$ & $\begin{array}{c}\mathbf{d}_{\mathbf{w} 2} \\
(\mathrm{~mm})\end{array}$ & $\begin{array}{c}\mathbf{d}_{\mathbf{w} \mathbf{1}} \\
(\mathrm{mm})\end{array}$ & $\begin{array}{c}\mathbf{d}_{\mathbf{f}} \\
(\mathrm{mm})\end{array}$ & $\begin{array}{c}\mathrm{t} \\
(\mathrm{mm})\end{array}$ & $\mathrm{R}$ \\
\hline \multirow{4}{*}{$\begin{array}{c}\text { Al-Zamil } \\
\text { Company }\end{array}$} & $\mathrm{S}-1$ & 1502 & 301 & 301 & 133 & 2 & 1.0 \\
\cline { 2 - 8 } & $\mathrm{S}-2$ & 1498 & 303 & 202 & 132 & 2 & 1.5 \\
\cline { 2 - 8 } & $\mathrm{S}-3$ & 1501 & 305 & 154 & 109 & 2 & 1.98 \\
\cline { 2 - 8 } & $\mathrm{S}-4$ & 1500 & 207 & 207 & 204 & 2 & 1.0 \\
\cline { 2 - 8 } Sabtia & $\mathrm{S}-5$ & 500 & 302 & 152.5 & 200 & 1.4 & 1.98 \\
\cline { 2 - 8 } & $\mathrm{S}-6$ & 750 & 304 & 157 & 204 & 2 & 1.93 \\
\hline \hline
\end{tabular}

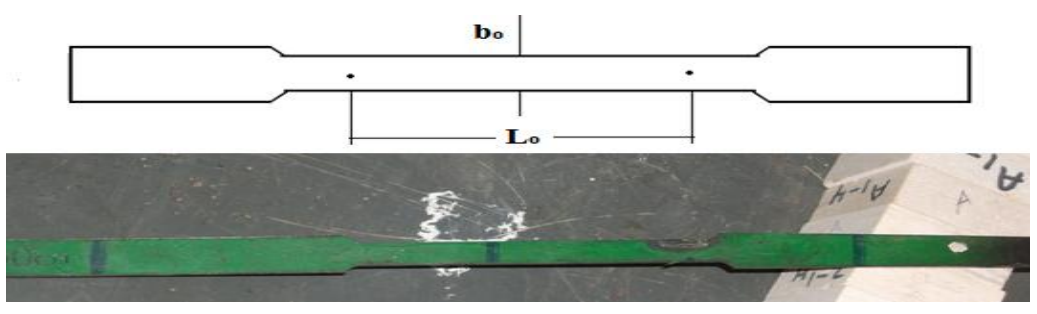

Fig. 2 Standard tensile coupon 
Table 2 Values of measured material properties

\begin{tabular}{c|c|c|c|c|c|c}
\hline \hline $\begin{array}{c}\text { source of } \\
\text { Material }\end{array}$ & Specimen & $\begin{array}{c}\boldsymbol{\sigma}_{\mathbf{y}} \\
\boldsymbol{t} / \mathbf{c m}^{\mathbf{2}}\end{array}$ & $\begin{array}{c}\boldsymbol{\sigma}_{\mathbf{u}} \\
\boldsymbol{t} / \mathbf{c m}^{2}\end{array}$ & $\boldsymbol{\sigma}_{u} / \boldsymbol{\sigma}_{y}$ & $\delta(\%)$ & $\begin{array}{c}\mathrm{E} \\
\boldsymbol{t} / \mathbf{c m}^{2}\end{array}$ \\
\hline \multirow{3}{*}{$\begin{array}{c}\text { Al-Zamil } \\
\text { Company }\end{array}$} & $\mathrm{S}-1$ & 2.6 & 3.35 & 1.288 & 38.46 & 2000 \\
\cline { 2 - 7 } & $\mathrm{S}-2$ & 2.7 & 3.5 & 1.296 & 40.77 & 1900 \\
\cline { 2 - 7 } & $\mathrm{S}-3$ & 2.5 & 3.06 & 1.224 & 25.7 & 1920 \\
\cline { 2 - 7 } & $\mathrm{S}-4$ & 2.75 & 3.5 & 1.27 & 37.14 & 2050 \\
\hline \multirow{3}{*}{ Sabtia } & $\mathrm{S}-5$ & 2.75 & 3.2 & 1.15 & 27 & 1100 \\
\cline { 2 - 7 } & $\mathrm{S}-6$ & 2.65 & 3.126 & 1.18 & 42.86 & 1250 \\
\cline { 2 - 7 } & $\mathrm{S}-7$ & 2.70 & 3.17 & 1.13 & 22.6 & 1250 \\
\hline \hline
\end{tabular}

\section{Finite Element Model}

Eight node quadrilateral thin shell element "Shell 93" with membrane and bending capabilities which is suitable for three dimensional structural analysis is used for the column cross section. The element has isotropic material properties and constant thickness. Generally, the flanges were divided into 8 elements for $\mathrm{d}_{\mathrm{w} 2} / \mathrm{d}_{\mathrm{f}}=1.5,6$ elements for $\mathrm{d}_{\mathrm{w} 2} / \mathrm{d}_{\mathrm{f}}=$ 2.0 and 2.5, and 4 elements for $\mathrm{d}_{\mathrm{w} 2} / \mathrm{d}_{\mathrm{f}}=3.0$. while the webs were divided into 12 elements for $\mathrm{d}_{\mathrm{w} 2} / \mathrm{d}_{\mathrm{w} 1}=1.0,10$ elements ford $\mathrm{w}_{2} / \mathrm{d}_{\mathrm{w} 1}=1.2,8$ elements for $\mathrm{d}_{\mathrm{w} 2} / \mathrm{d}_{\mathrm{w} 1}=1.4$, and 6 elements for $\mathrm{d}_{\mathrm{w} 2} / \mathrm{d}_{\mathrm{w} 1}=2.0$. The column is divided into 60 elements in the longitudinal direction. End plate of thickness $30 \mathrm{~mm}$ was used at each end of the model to avoid stress concentration at the locations of the column loading and supporting points. To represent the two supports the nodes of one of the two ends-plates is restrained from translation in the three main directions $\left(\mathrm{U}_{\mathrm{x}}, \mathrm{U}_{\mathrm{y}}\right.$ and $\left.\mathrm{U}_{\mathrm{z}}\right)$ in addition to rotation about longitudinal axis $\left(\mathrm{r}_{\mathrm{y}}\right)$, while the nodes of the second end plate is restrained from translation in the two main directions $\left(U_{x}\right.$ and $\mathrm{U}_{\mathrm{z}}$ ) and rotation about longitudinal axis $\left(\mathrm{r}_{\mathrm{y}}\right)$; translation is allowed in the direction of the longitudinal axis column to allow the column to deform longitudinally due to normal force (P). The axial compressive force acting on the analyzed columns is applied as concentrated load at the middle node of end plate which is free to move longitudinally. This load is increased incrementally until failure takes place. Ultimate loads are then calculated by multiplying all defined loading by the corresponding load factors. The material properties is assumed to be bilinear with Young's modulus of elasticity $\left(E=210000 \mathrm{~N} / \mathrm{mm}^{2}\right)$ and with tangent modulus $\left(E_{t}=2000 \mathrm{~N} / \mathrm{mm}^{2}\right)$ to account for strain hardening . Poisson's ratio is taken equal to 0.3. The numerical procedure used in the static analysis is the Modified Newton-Raphson scheme (MNR). Nonlinear finite element analysis through ANSYS program was executed and both geometrical and material nonlinearities were considered. Arc-length control method is adopted throughout the parametric study.

\section{Comparison of Experimental Test Results with ANSYS Software}

The comparison between the results of experimental work and those obtained from finite element program is tabulated in Table 3. It is clear that the finite element results are in very good agreement with experimental results. Figure 3 shows the deformed shape for column (S-7), while Figure 4 provides the load-end shortening relationship of the columns (S-1) and $(\mathrm{S}-5)$. 
Table 3 Comparison of experimental and numerical results of hollow section tapered columns tested

\begin{tabular}{c|c|c|c|c|c|c|c|c}
\hline \hline Specimen & $\begin{array}{c}\mathrm{L} \\
(\mathrm{mm})\end{array}$ & $\begin{array}{c}\mathbf{d}_{\mathbf{w} 2} \\
(\mathrm{~mm})\end{array}$ & $\begin{array}{c}\mathbf{d}_{\mathbf{w} 1} \\
(\mathrm{~mm})\end{array}$ & $\begin{array}{c}\mathbf{d}_{\mathbf{f}} \\
(\mathrm{mm})\end{array}$ & $\begin{array}{c}\mathrm{t} \\
(\mathrm{mm})\end{array}$ & $\begin{array}{c}\boldsymbol{P}_{\boldsymbol{u}}^{\text {tes }} \\
(\text { ton })\end{array}$ & $\begin{array}{c}\boldsymbol{P}_{\boldsymbol{u}}^{\boldsymbol{F} \cdot \boldsymbol{E}} \\
(\text { ton })\end{array}$ & $\begin{array}{c}\text { deviation } \\
(\%)\end{array}$ \\
\hline S-1 & 1502 & 301 & 301 & 133 & 2 & 19.5 & 21.81 & 10.6 \\
\hline S-2 & 1498 & 303 & 202 & 132 & 2 & 19.25 & 20.485 & 6 \\
\hline S-3 & 1501 & 305 & 154 & 109 & 2 & 16.40 & 18.745 & 12.5 \\
\hline S-4 & 1500 & 207 & 207 & 204 & 2 & 20.60 & 21.254 & 3.07 \\
\hline S-5 & 500 & 302 & 152.5 & 200 & 1.4 & 10.00 & 9.289 & 7.11 \\
\hline S-6 & 750 & 304 & 157 & 204 & 2 & 17.00 & 17.69 & 3.9 \\
\hline S-7 & 1000 & 299 & 155 & 199 & 2 & 16.5 & 17.6 & 6.25 \\
\hline \hline
\end{tabular}

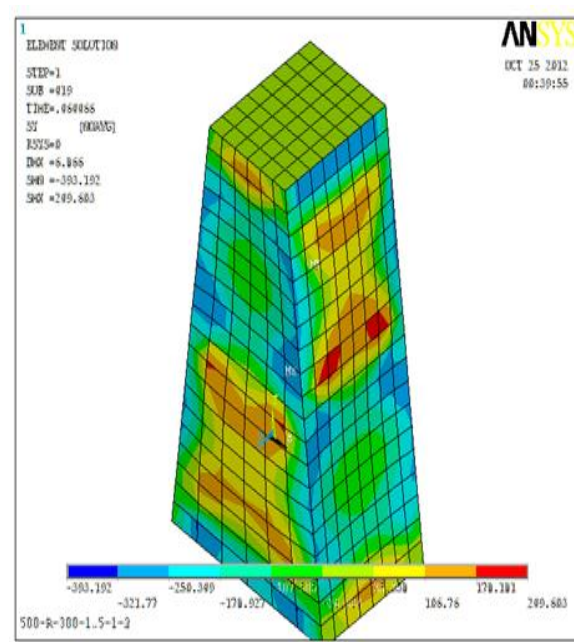

(a)- F. E. modeling

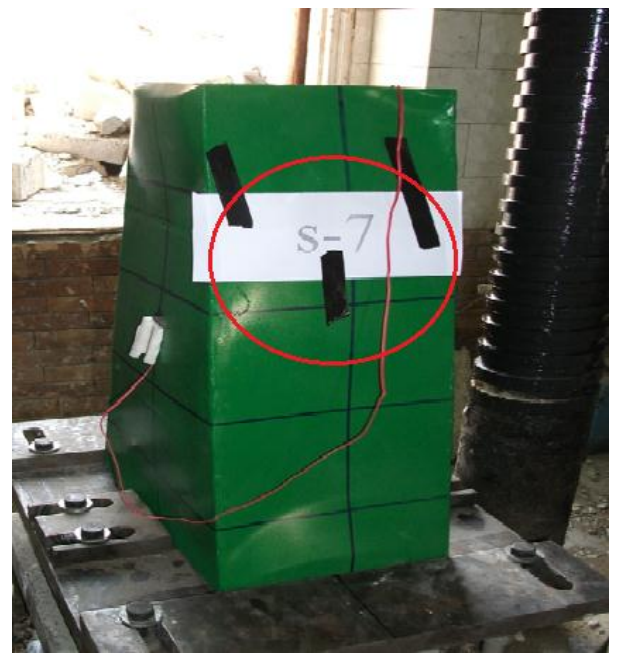

(b)-Experimental

Fig. 3 Deformed shape of column S-7

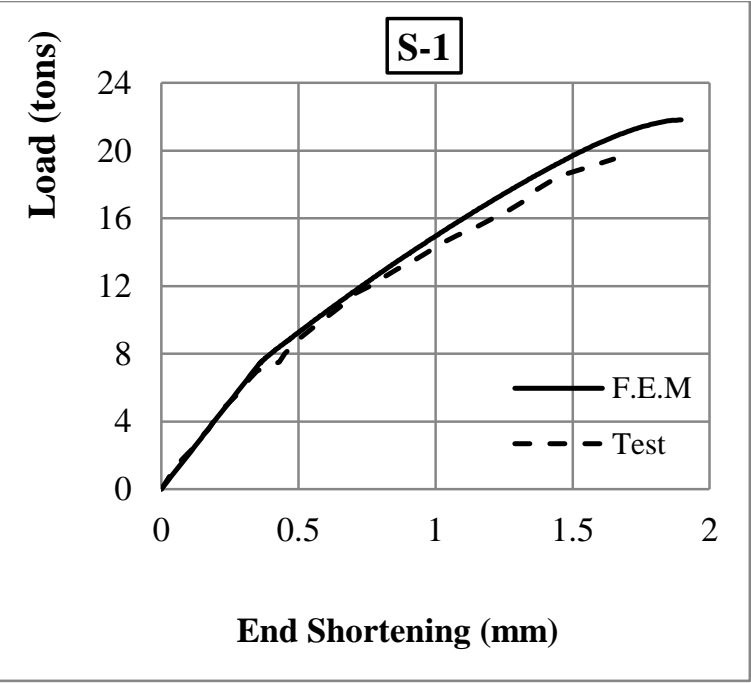

(a)- Column S-1

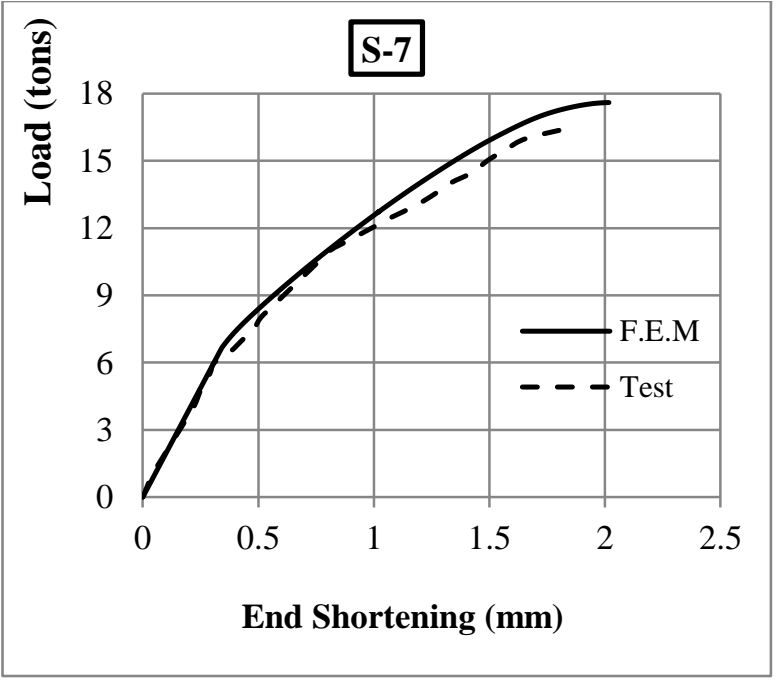

(b)- Column S-7

Fig. 4 Load-End Shortening relationship 


\section{Parametric Study}

A parametric study on axially loaded RHS columns is performed using the proposed finite element model. The length $L$ and bottom web end depth $d_{w 2}$ of all the columns is fixed throughout the parametric study with a values equal to 1500 and 300 millimeters, respectively, with different values of tapering ratio $\mathrm{R}=\mathrm{d}_{\mathrm{w} 2} / \mathrm{d}_{\mathrm{w} 1}$ equal to $(1,1.2,1.4,1.714$ and 2.0), different values of web depth-to- flange width ratio $\mathrm{d}_{\mathrm{w} 2} / \mathrm{d}_{\mathrm{f}}$ equal to $(1.5,2.0,2.5$ and 3.0).Various values of thickness $t$ were considered, these values were varied to make bottom end's web depth-to-thickness ratio $\mathrm{d}_{\mathrm{w} 2} / \mathrm{t}$ equal to $(300,250,200,150,100$ and 50).

\section{Results and Discussion}

The results are presented diagrammatically as function of the ratio of the ultimate load to average area yield load $\left(\mathrm{P}_{\mathrm{u}} / \mathrm{P}_{\mathrm{y}, \mathrm{av}}\right)$ with respect to the different effective parameters.

\subsection{Effect of Web Depth-To-Thickness Ratio " $d_{w 2} / t$ "}

Figures 5 to 8 represent the relationship between the ratio of ultimate load to average area yield load $\left(\mathrm{P}_{\mathrm{u}} / \mathrm{P}_{\text {yav }}\right)$ versus wide web depth -to- thickness ratio $\mathrm{d}_{\mathrm{w} 2} / \mathrm{t}$ for various values of wide web depth -to-flange width ratio $\left(\mathrm{d}_{\mathrm{w} 2} / \mathrm{d}_{\mathrm{f}}\right)$ and different values of tapering ratio" $\mathrm{R}$ " for hollow rectangular section tapered columns. It is clear from these curves that the relationship between the ultimate load to average area yield load ratio $\left(\mathrm{P}_{\mathrm{u}} / \mathrm{P}_{\text {yav }}\right)$ and bottom web depth to- thickness ratio $\mathrm{d}_{\mathrm{w} 2} / \mathrm{t}$ is an inversely proportional relationship as $\left(\mathrm{P}_{\mathrm{u}} / \mathrm{P}_{\mathrm{yav}}\right)$ increases with the decrease of $\mathrm{d}_{\mathrm{w} 2} / \mathrm{t}$. This can be explained as the possibility of occurrence of local buckling of component plates of the section. Also, it can be noticed that, $\left(\mathrm{P}_{\mathrm{u}} / \mathrm{P}_{\mathrm{yav}}\right)$ increases with the increase of tapering ratio $(\mathrm{R})$.

\subsection{Effect of Web Depth-To-Flange Width Ratio $d_{w 2} / d_{f}$}

Figures 9 to 12 represent the relationship between the ratio of ultimate load to average area yield load $\left(\mathrm{P}_{\mathrm{u}} / \mathrm{P}_{\text {yav }}\right)$ versus bottom web depth -to- flange width ratio $\left(\mathrm{d}_{\mathrm{w} 2} / \mathrm{d}_{\mathrm{f}}\right)$ for various values of tapering ratio $R$ and different values of wide web depth-to-thickness ratio $d_{w 2} / t$ for hollow rectangular section tapered columns. It is clear from these curves that the relationship between the ultimate load to average area yield load ratio $\left(\mathrm{P}_{\mathrm{u}} / \mathrm{P}_{\text {yav }}\right)$ and wide web depth -toflange width ratio $\left(\mathrm{d}_{\mathrm{w} 2} / \mathrm{d}_{\mathrm{f}}\right)$ is a directly proportional relationship as $\left(\mathrm{P}_{\mathrm{u}} / \mathrm{P}_{\mathrm{yav}}\right)$ increases with the increase of $\left(d_{w 2} / d_{f}\right)$. This is because the increase of $\left(d_{w 2} / d_{f}\right)$ makes the flange more stiff which in turn makes a better restraint to the webs and so reduces the effect of local buckling. It is clear that for all values of $\mathrm{d}_{\mathrm{w} 2} / \mathrm{t}=50$, any value of $\mathrm{R}$ except for $\mathrm{R}$ greater than 1.4 , the increase of $\left(\mathrm{d}_{\mathrm{w} 2} / \mathrm{d}_{\mathrm{f}}\right)$ almost has no effect on the ultimate capacity of the section and it is equal to unity. 


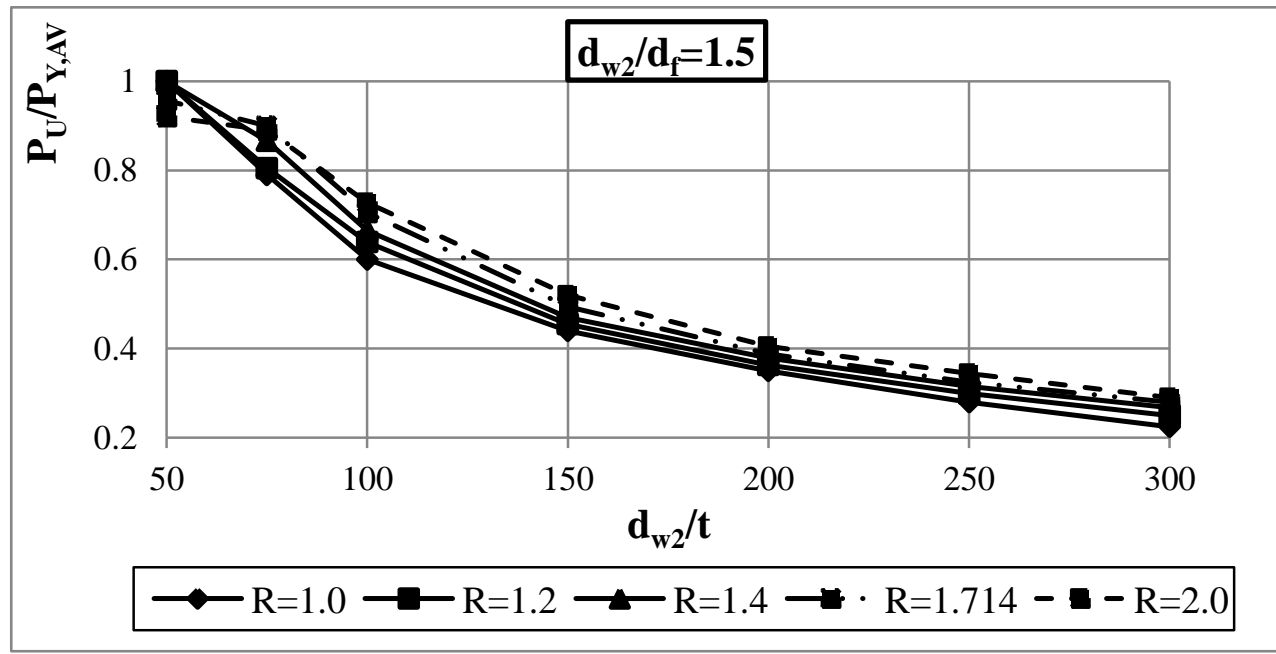

Fig. 5 Effect of the ratios $\left(d_{w 2} / t\right)$ on strength of $\mathrm{HSC}$ for different values of " $R$ " $\left(a t d_{w 2} / d_{f}=1.5\right)$

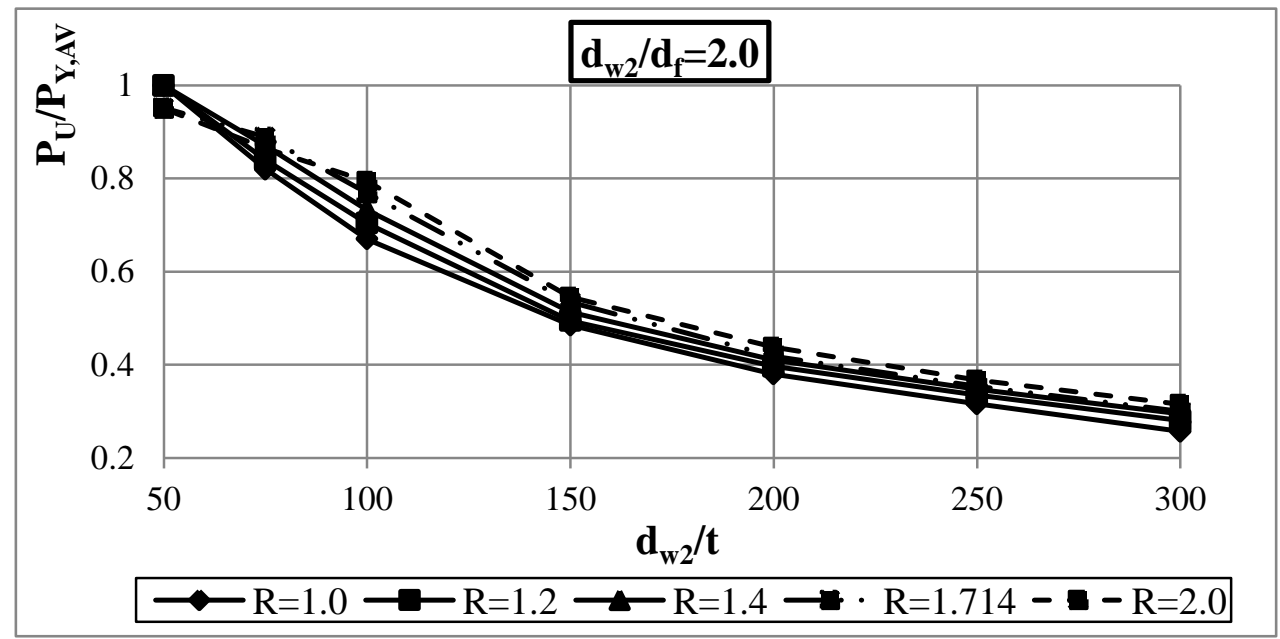

Fig. 6 Effect of the ratios $\left(d_{w 2} / t\right)$ on strength of HSC for different values of " $R$ " $\left(\right.$ at $\left.d_{w 2} / d_{f}=2.0\right)$

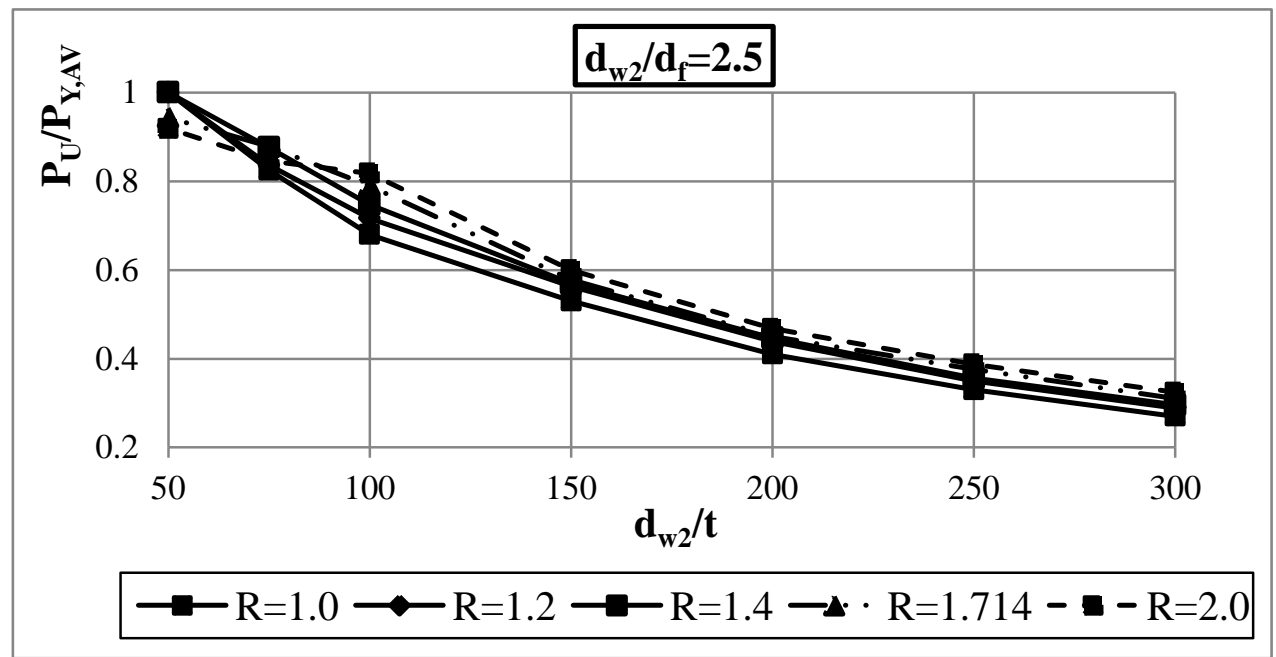

Fig. 7 Effect of the ratios $\left(d_{w 2} / t\right)$ on strength of HSC for different values of "R" $\left(a t d_{w 2} / d_{f}=2.5\right)$ 


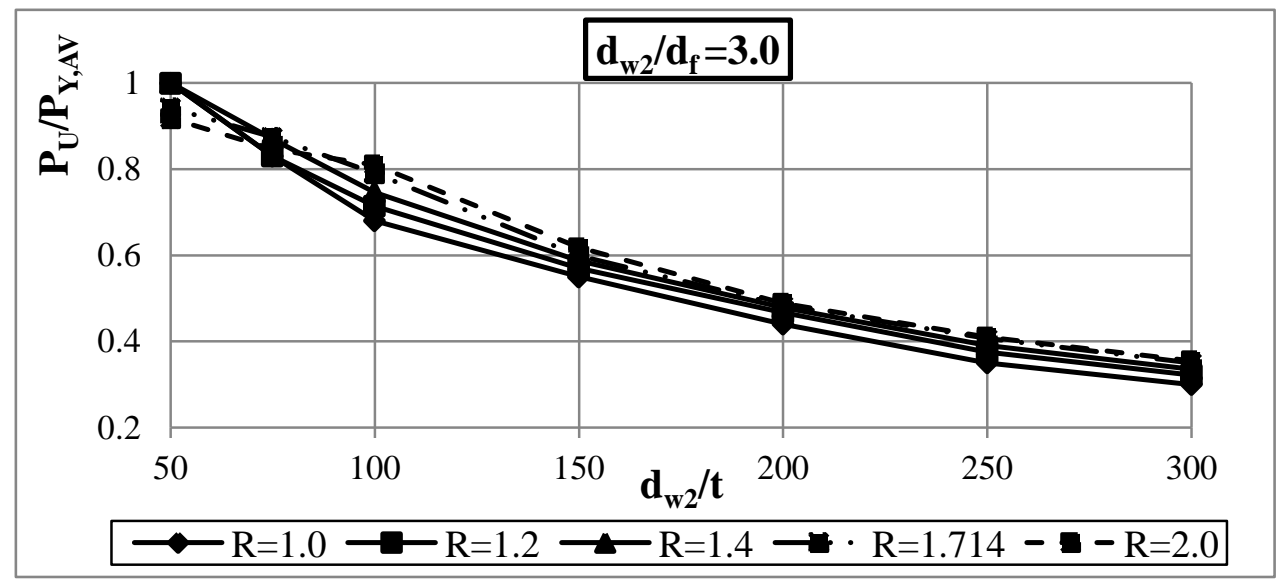

Fig. 8 Effect of the ratios $\left(d_{w 2} / t\right)$ on strength of HSC for different values of "R" (at $\left.d_{w 2} / d_{f}=3.0\right)$

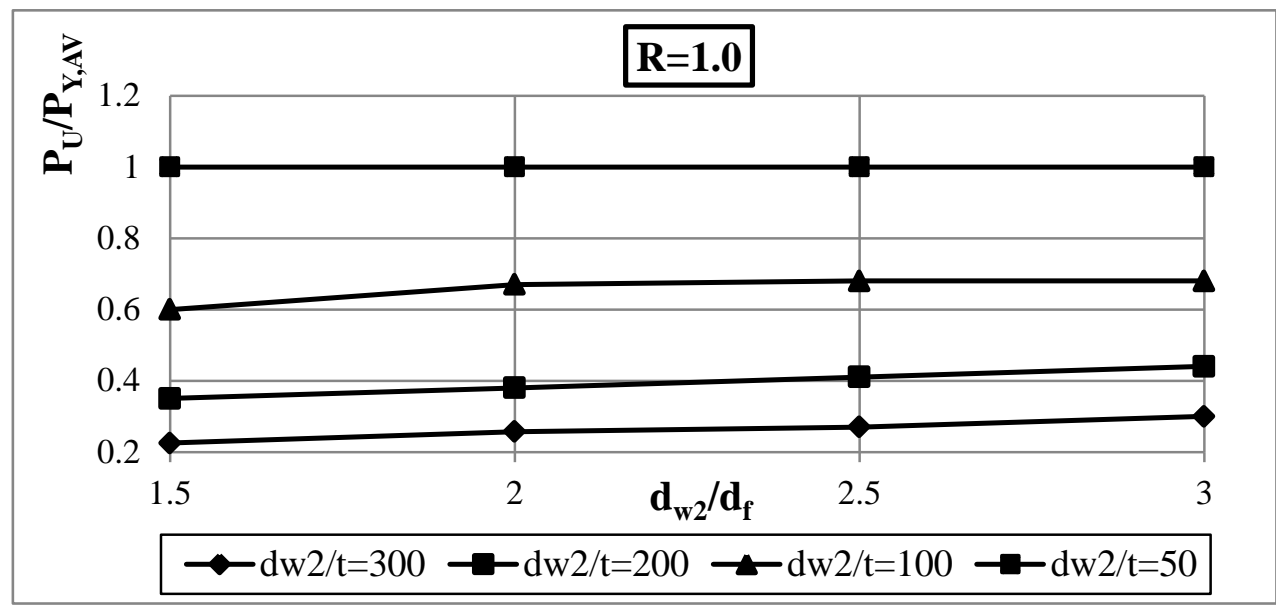

Fig. 9 Effect of the ratios $\left(d_{w 2} / d_{f}\right)$ on strength of HSC for different values of " $d_{W 2} / t$ " (at $\left.R=1.0\right)$

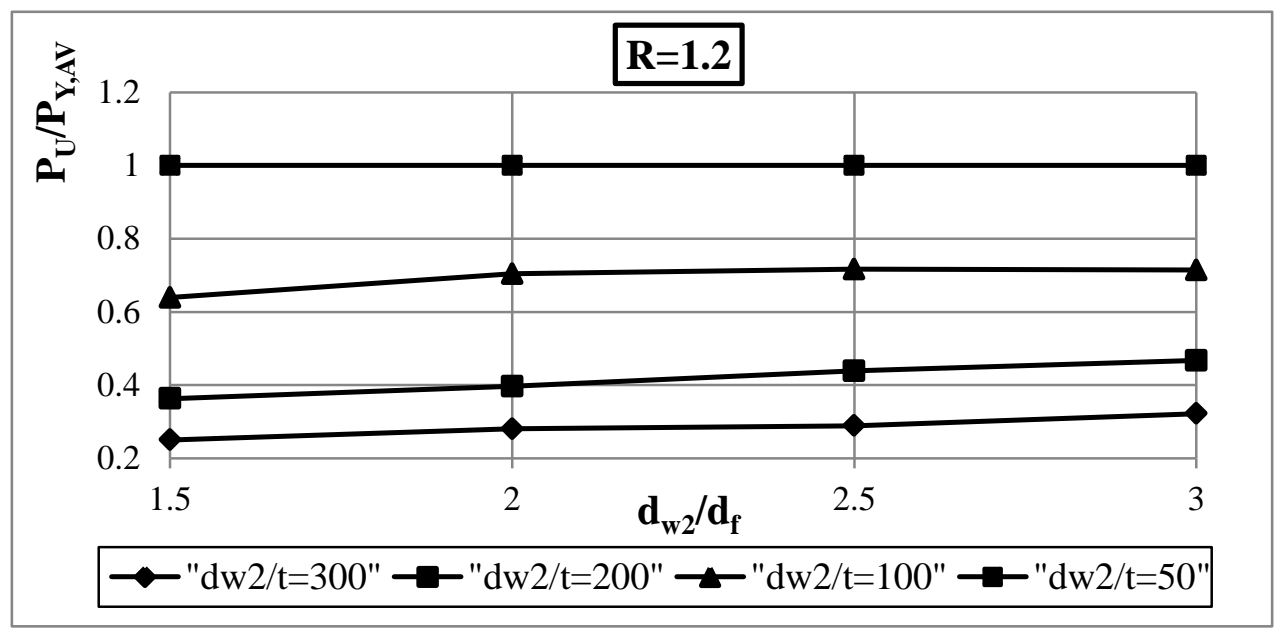

Fig. 10 Effect of the ratios $\left(d_{w 2} / d_{f}\right)$ on strength of HSC for different values of " $d_{W 2} / t$ " (at $\left.R=1.2\right)$ 


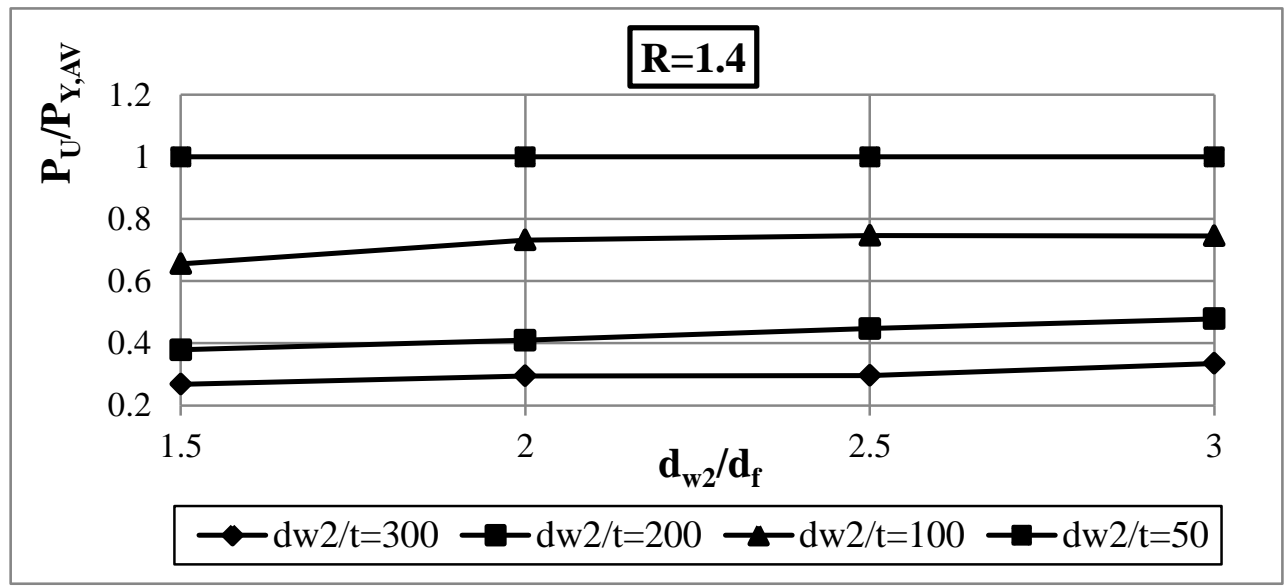

Fig. 11 Effect of the ratios $\left(d_{w 2} / d_{f}\right)$ on strength of HSC for different values of " $d_{W 2} / t$ " (at $\left.R=1.4\right)$

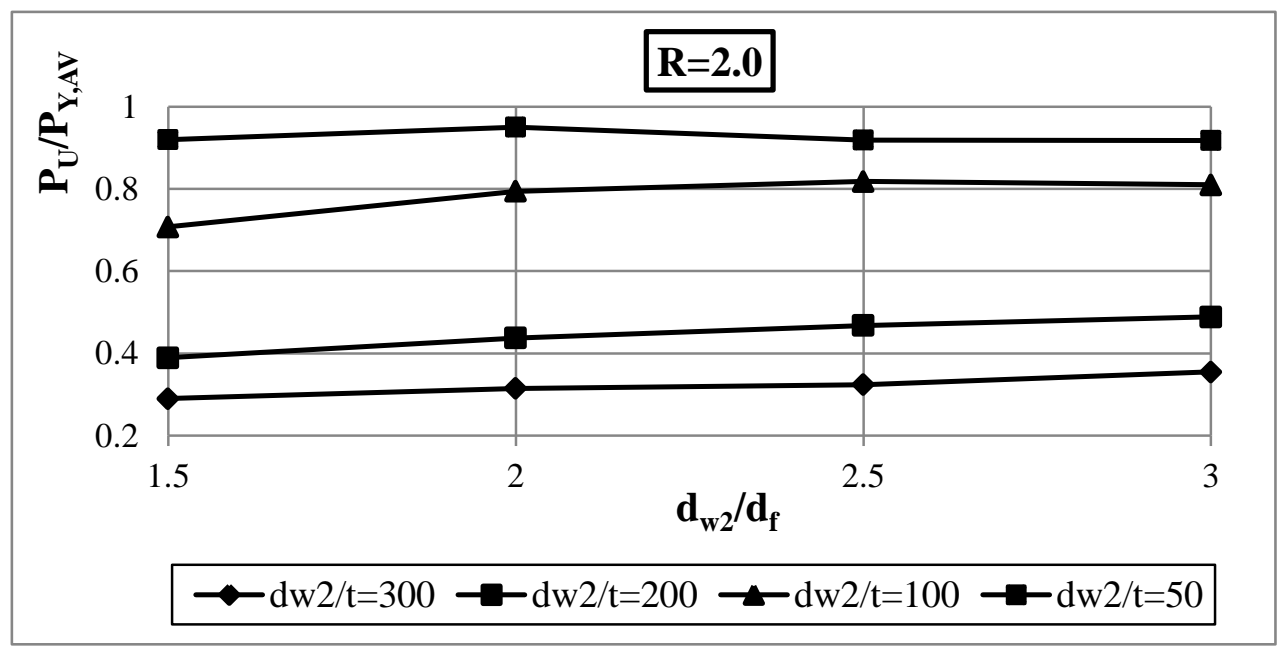

Fig. 12 Effect of the ratios $\left(d_{w 2} / d_{f}\right)$ on strength of HSC for different values of " $d_{w 2} / t " \quad($ at $R=2.0)$

\section{Comparison between AISI-2001 and EN-1993 Codes and F.E.M.}

The results obtained from the previously mentioned finite element analyses are compared with the American (AISI-2001) and European (EN-1993) specifications. This comparison is illustrated in a set of curves for some studied columns used in the parametric study.

The AISI-2001 equation used to get the nominal unfactored axial strength of thin-walled boxsection columns is:

$P_{n}=A_{e} \times F_{n}$

Where, "P $\mathrm{P}_{\mathrm{n}}$ " is the nominal axial strength and " $\mathrm{A}_{\mathrm{e}}$ " is the "effective" area at a stress value equal to " $\sigma_{\mathrm{n}}$ ". The stress " $\sigma_{\mathrm{n}}$ " is determined as follows:

$\sigma_{\mathrm{n}}=\left(0.658^{\lambda_{c}^{2}}\right) \times \sigma_{\mathrm{y}}$ if $\lambda_{c} \leq 1.5$

$\sigma_{\mathrm{n}}=\left[\frac{0.877}{\lambda_{c}^{2}}\right] \times \sigma_{\mathrm{y}} \quad$ if $\lambda_{c}>1.5$

The EN-1993equation used to get the nominal unfactored axial strength of thin-walled boxsection columns is: 
$\mathrm{N}_{\mathrm{b}, \mathrm{Rd}}=\chi \mathrm{A}_{\mathrm{e}} \times \sigma_{\mathrm{y}} / \gamma_{\mathrm{M} 1}$

Where, " $\mathrm{N}_{\mathrm{b}, \mathrm{Rd}}$ " - is the resistance to flexural buckling, and " $\chi$ " - is the reduction factor accounting for buckling.

Figures 13 to 16 represent the relationship between the ratio of ultimate load to average area yield $\operatorname{load}\left(\mathrm{P}_{\mathrm{u}} / \mathrm{P}_{\mathrm{y}, \text { av }}\right)$ versus bottom web depth -to- thickness ratio $\mathrm{d}_{\mathrm{w} 2} / \mathrm{t}$ for the AISI-2001, EN-1993 and finite element results for $\left(\mathrm{d}_{\mathrm{w} 2} / \mathrm{d}_{\mathrm{f}}\right)=1.5,2.0,2.5$, and 3.0 at tapering ratio $(\mathrm{R})$ equal to 1.0. It is obvious from all Figures that both the AISI-2001and EN-1993 results give the same ultimate strength for all columns. It can be also noticed that both the AISI-2001and EN-1993, codes give very similar results with those of the finite element in the range $d_{w 2} / t$ between 100 and 300 for $\left(\mathrm{d}_{\mathrm{w}_{2}} / \mathrm{d}_{\mathrm{f}}\right)=1.5$ and 2.0. For $\left(\mathrm{d}_{\mathrm{w} 2} / \mathrm{d}_{\mathrm{f}}\right)=2.5$ and 3.0 both codes and finite element results are almost parallel, which means that the codes express the same behavior of the finite element but in a conservative manner.

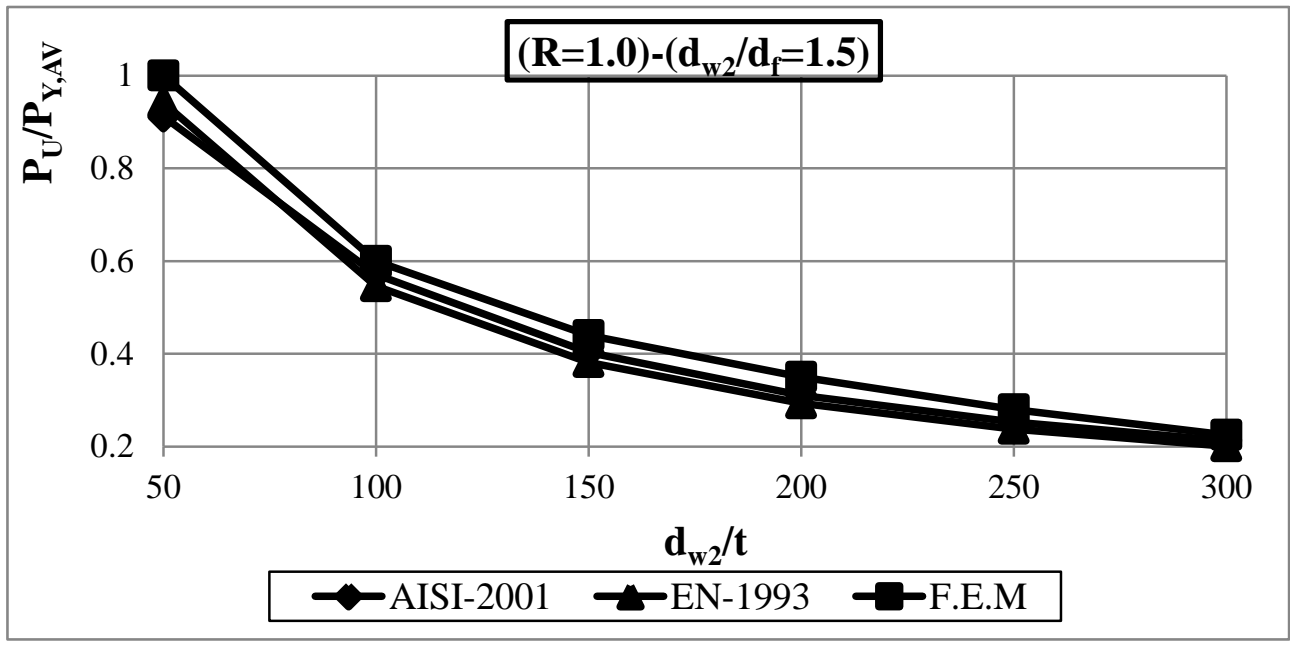

Fig. 13 Comparison between AISI-2001, EN-1993 and F.E.M. results for $\left(\mathbf{d}_{\mathbf{w}_{2}} / \mathbf{d}_{\mathbf{f}}=1.5\right)$

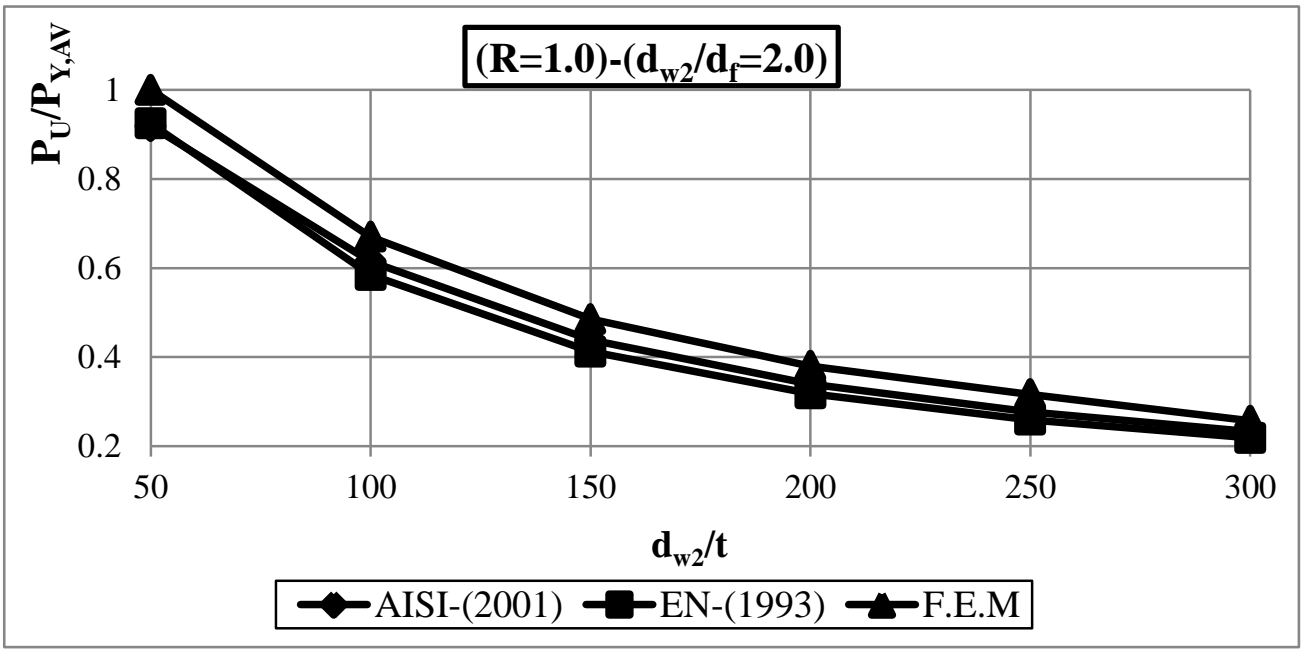

Fig. 14 Comparison between AISI-2001, EN-1993 and F.E.M. results

$$
\operatorname{for}\left(d_{w_{2}} / d_{f}=2.0\right)
$$




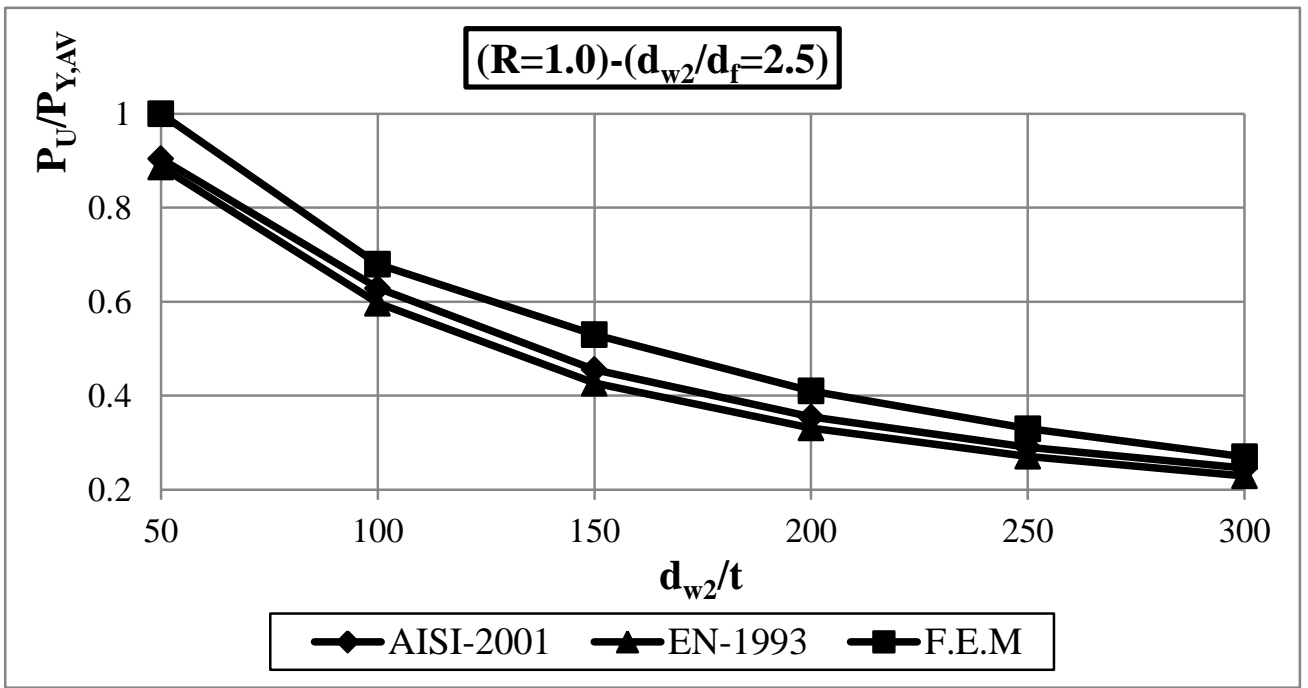

Fig. 15 Comparison between AISI-2001, EN-1993 and F.E.M. results

$$
\text { for }\left(d_{w_{2}} / d_{f}=2.5\right)
$$

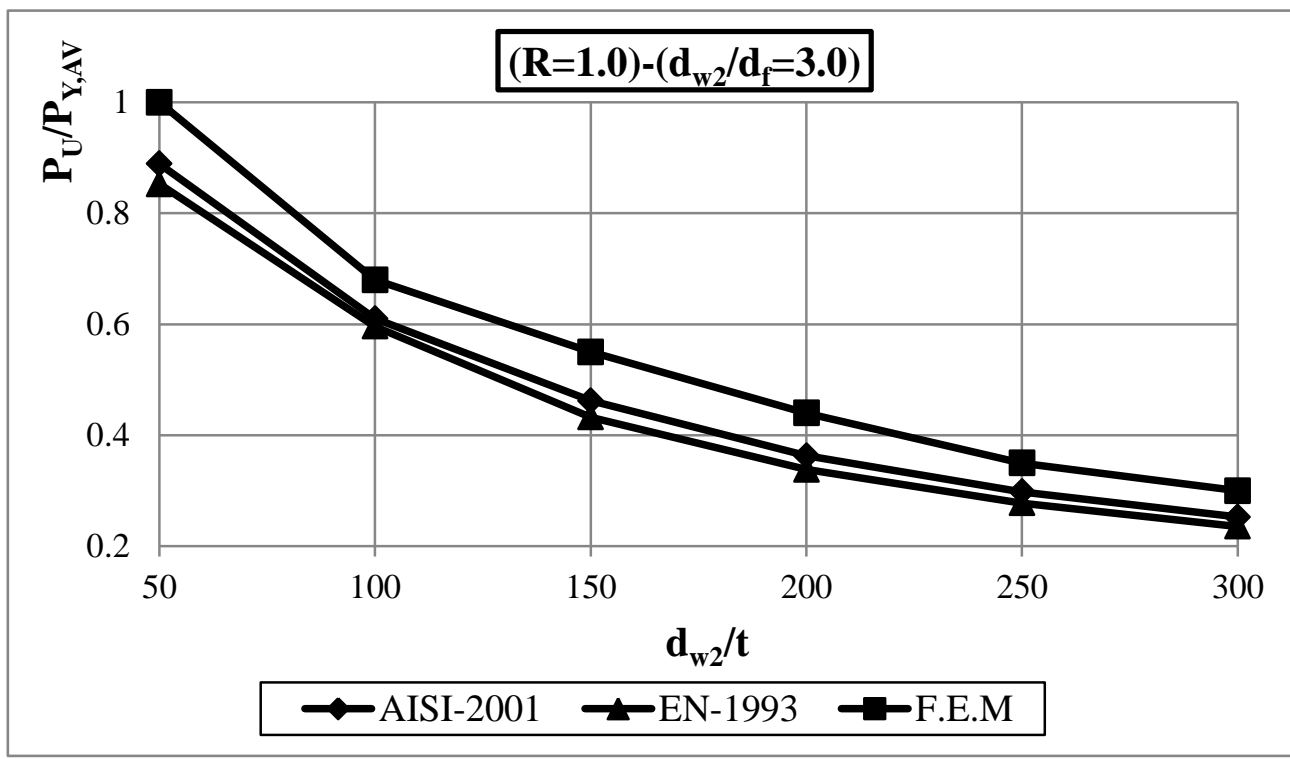

Fig. 16 Comparison between AISI-2001, EN-1993 and F.E.M. results for $\left(d_{w_{2}} / d_{f}=3.0\right)$

\section{Conclusions}

In this paper, the behavior of rectangular hollow sections tapered columns was investigated experimentally and analytically. Seven columns with different shapes and dimensions were tested under concentric loading. Numerical modeling was conducted to study the strength of rectangular hollow sections tapered columns subjected to uniform axial loads. The numerical modeling was verified using the experimental results. Good agreement of the proposed model was noticed with the experimental tests. The numerical modeling was, then, expanded through a parametric study. The following main conclusions are obtained from this study:

The failure mode and the ultimate load of RHS axially loaded tapered columns depend on the geometrical dimensions of the cross-section $\left(\mathrm{d}_{\mathrm{w} 2}, \mathrm{~d}_{\mathrm{w} 1}, \mathrm{~d}_{\mathrm{f}}\right.$ and $\left.\mathrm{t}\right)$. 
The relationship between the ultimate load to average area yield load ratio $\left(\mathrm{P}_{\mathrm{u}} / \mathrm{P}_{\mathrm{yav}}\right)$ and bottom web depth -to- thickness ratio $\mathrm{d}_{\mathrm{w} 2} / \mathrm{t}$ is an inversely proportional relationship as $\left(\mathrm{P}_{\mathrm{u}} / \mathrm{P}_{\text {yav }}\right)$ increases with the decrease of $" \mathrm{~d}_{\mathrm{w} 2} / \mathrm{t}$ " .

The relationship between the ultimate load to average area yield load ratio $\left(\mathrm{P}_{\mathrm{u}} / \mathrm{P}_{\mathrm{yav}}\right)$ and wide web depth -to- flange width ratio $\left(\mathrm{d}_{\mathrm{w} 2} / \mathrm{d}_{\mathrm{f}}\right)$ is a directly proportional relationship as $\left(\mathrm{P}_{\mathrm{u}} / \mathrm{P}_{\text {yav }}\right)$ increases with the increase of $\left(\mathrm{d}_{\mathrm{w} 2} / \mathrm{d}_{\mathrm{f}}\right)$.

The increase of $\left(\mathrm{d}_{\mathrm{w} 2} / \mathrm{d}_{\mathrm{f}}\right)$ almost has no effect on the ultimate capacity of the section and it's equal to unity for all values of $\mathrm{d}_{\mathrm{w} 2} / \mathrm{t}=50$, and $\mathrm{R}$ except for $\mathrm{R}$ greater than 1.4.

The increase of tapering ratio $(\mathrm{R})$ generally increases the values of the ultimate loads.

The reduction of slenderness of flanges provides more restraint to the webs and reduces the effect of local buckling.

Making the web depth double the flange width is enough to give the web a good restraint.

Both AISI-2001and EN-1993 Codes yield conservative ultimate strength for columns when compared to the finite element results.

\section{Acknowledgements}

The authors are grateful to administration of Al-Zamil company, especially Engs. Khaled Saad and Ashraf Younis for providing assistance the manufactured the tested columns as well as for their valuable advice and technical contribution. Thanks are also due to the Civil Engineering Laboratory Ain Shams University where the experiments were carried out.

\section{References}

[1] R.Q. Bridge, M.D.O'Shea" Behaviour of thin-walled steel box sections with or without internal restraint" Journal of Constructional Steel Research 47 (1998).

[2] Ben Young" Experimental and numerical investigation of high strength stainless steel structures" Journal of Constructional Steel Research in Compression" Research Report No R813, Centre for Advanced Structural Engineering, Sydney; (2002).

[3] D. Yang, G.J. Hancock and K.J. Rasmussen" Compression Tests of Cold-Reduced High Strength Steel Long Columns" Centre for Advanced Structural Engineering, Research Report No 816 (2002).

[4] A. H. Salem et al."Ultimate Strength of Cold-Formed RHS Columns" Tenth International Colloquium on Structural and Geotechnical Engineering, Ain Shams Univ. Cairo- Egypt (2003).

[5] H. Kuwamura "Local Buckling of Thin-Walled Stainless Steel Members" Steel Structures 3 (2003).

[6] M.A. Korashy, et,al "New Proposed Slenderness Ratio for Thin-Walled Box-Section Beam-Columns" $12^{\text {th }}$ ICSGE, Ain Shams Univ. Cairo-Egypt (2007).

[7] Dabaon, et al."Numerical Modeling for Stiffened and Unstiffened Stainless Steel Hollow Tubular Columns" 13th ICSGE, Ain Shams Univ. Cairo- Egypt (2009).

[8] R. Masoudnia, et,al" Numerical Investigation of Behavior of RHS Columns Using FE Method" European Journal of Scientific Research ,Vol.51 No.1 (2011). 